\title{
MODELLING OF IRON ORE PROCESSING IN TECHNOLOGICAL UNITS BASED ON THE HYBRID APPROACH
}

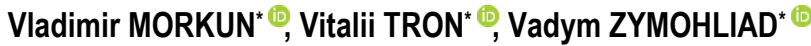 \\ "Department of Automation, Computer Science and Technologies, Kryvyi Rih National University, \\ Vitalii Matusevich St., 11, Kryvyi Rih, Ukraine \\ morkunv@gmail.com, vtron@ukr.net, zimogladvadim@gmail.com
}

received 7 November 2020, revised 20 December 2021, accepted 22 December 2021

\begin{abstract}
The process line of concentrating iron ore materials is considered as a sequence of connected concentration units, some of which partially return ore materials to the previous unit. The output product of the final concentration unit in the process line is the end product of the whole line. Characteristics of ore, such as distribution of ore particles by size and distribution of iron content by size classes, are considered. Processing of iron ore materials by process units (a cycle, a scheme) is characterised by a separation characteristic namely the function of extracting elementary fractions depending on physical properties of ore particles. The results of fraction analysis of ore samples in different points of the process line provide an experimental definition of separation characteristics and numerical values of the Rosin-Rammler equation factors. To identify dependencies that cannot be analytically described, the hybrid approach accompanied by the Takagi-Sugeno fuzzy models, in accompaniment with triangular membership functions determining fuzzy sets in preconditions, are used. To identify fuzzy sets in rule preconditions, triangular membership functions are used. Introduction of a-priori data on iron ore concentration as constraints for model parameters is a promising trend of further research, since it enables increased accuracy of identification despite limited availability of experimental data.
\end{abstract}

Key words: iron ore, Rosin-Rammler, fuzzy model, separation characteristics

\section{INTRODUCTION}

Iron ore processing is influenced by a variety of factors to varying extents. Among them, the following groups of factors are distinguished [23, 28-29, 34]: characteristics of mineralogical composition of ore; parameters of crushing machines determining the rate of size reduction of crushed ore; parameters determining grinding indices; parameters determining floatation processes. Based on this list, certain basic trends are distinguished in solving the problems of enhancing productivity of a concentration plant in terms of a marketable product $[6,7,36,37]$ : developing efficient regulations of the process conduction and upgrading technological equipment; designing automated control systems for concentration processes considering technological properties of processed ore; creating the system of automatic control over critical modes of technological processes and the expert decision support system.

The resulting separation characteristic of ore materials with a working point in the optimal cut-point is an essential indicator of improving the technological line of ore concentration [21, 22]. In technological flows of the ore concentration line at various stages, critically different types of ore materials in terms of their physicalmechanical and chemical-mineralogical characteristics are subjected to concentration; it is therefore expedient to investigate into the formation of a separation characteristic of technological concentration processes based on operating data on dynamics of their parameters $[5,20,26]$.

Technological processes of ore-concentrating plants involve multi-staged crushing and grinding to prepare ore for subsequent separation $[17,32]$. The operations are aimed at releasing ore grains and extracting particles of various minerals by reducing grain sizes up to $0.1 \mathrm{~mm}$ and less. In some cases, the size of the impregnated useful component covers several size classes used to assess granulometric composition of concentration products at mining and concentration plants (Fig. 1): ' +3 ', ' $-3+1$ ', ' $-1+0.5$ ', '-0.5 + 0.25', '-0.25 + 0.125', '-0.125+0.071', '-0.071+0.056', '-0.056 + 0.044', '-0.044+0'.

\section{LITERATURE ANALYSIS}

According to the research results [15-16, 32], to obtain quantitative evaluation of mineral products, except for the factor of mineral particles distribution $\gamma(\xi)$ by fractions with different physical properties $\xi$, the factor of useful components distribution $\beta(\xi)$ should also be used. The factors $\gamma(\xi)$ and $\beta(\xi)$ enable quantitative evaluation of ore materials. To facilitate quantitative evaluation of efficiency of process units, the authors suggest using separation characteristics $\varepsilon(\xi)$ determining the value of extracting $\varepsilon$ of mineral fractions into concentration products. The useful component is extracted into concentrate from the initial ore materials due to different physical properties $\xi$ of a given component and accompanying minerals. In working zones of concentration units, particles are separated under the influence of physical forces. Particles with some physical properties $(\xi>\xi p)$ move to one section of the working zone (concentrate), while particles with other properties $(\xi<\xi p)$ move to the other (tailings). 


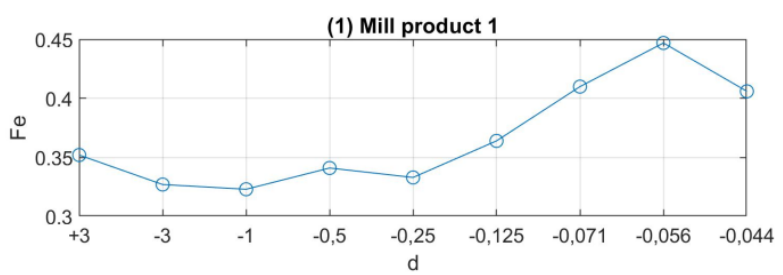

a)

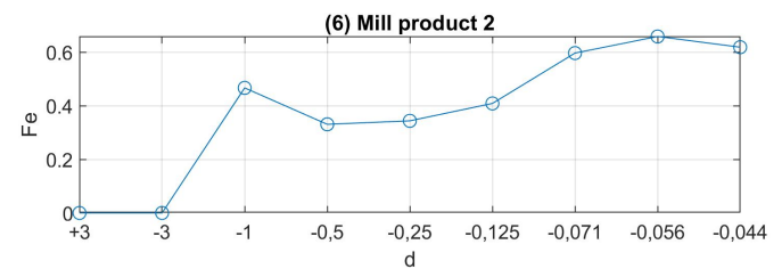

c)

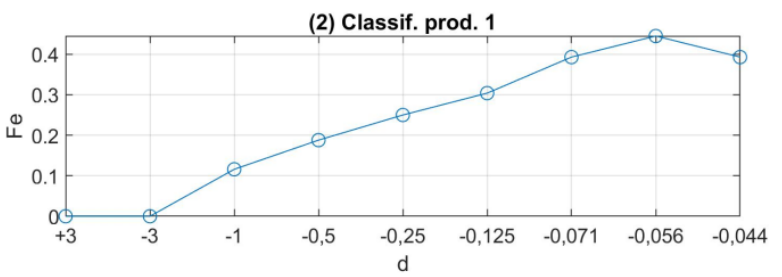

(b)

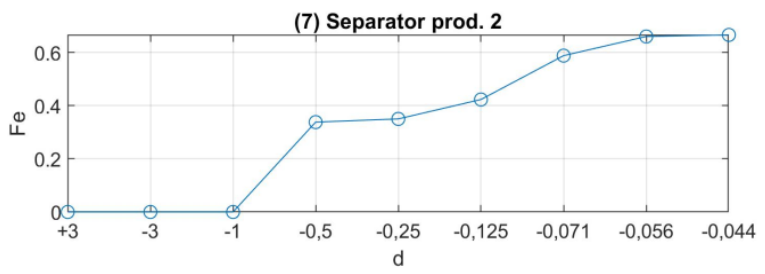

(d)

Fig. 1. Iron distribution by ore size classes at various points of the technological process

\section{RESEARCH METHODS}

In a general case, concentration units as control objects are operators transforming vectors of input variables into those of output variables. In compliance with this approach, the technological line of iron ore concentration is referred to as a set of $n$ connected concentration units (Fig. 2). The first unit of the process line - usually a ball mill of wet grinding [19] - is fed with raw materials of $Q_{0}^{(\mathrm{P})}$ volume with certain qualitative characteristics $\bar{\xi}_{0}$. These characteristics include $[23,26]$ : distribution of raw materials by size; distribution of $\mathrm{Fe}_{\text {tot }}$ and $\mathrm{Fe}_{\text {mag }}$ content by size classes. Intermediate concentration product produced at the output of the first technological unit is a raw material for the next unit or it is partially returned to the previous unit for additional processing. A spiral classifier, a hydrocyclone and a deslimer are examples of concentration units that return insufficiently ground ore particles. The final product of the last concentration unit in the process line, which is usually a magnetic separator, is concentrate, the end product of a given line.

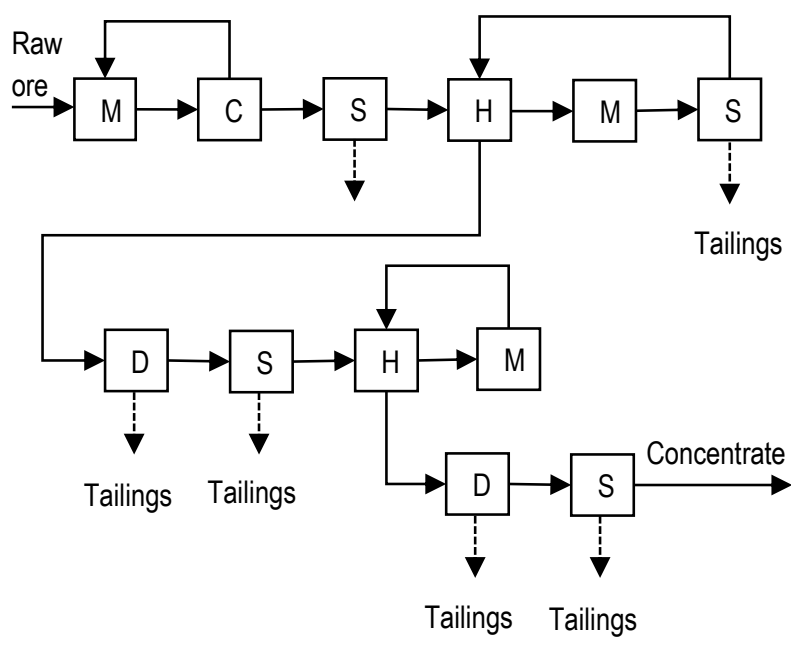

Fig. 2. Structural scheme of technological lines of iron ore concentration: $\mathrm{M}$ - mill, C - classifier; $\mathrm{S}$ - magnetic separator; $\mathrm{H}$ - hydrocyclone; D - deslimer
Output parameters of each process unit $y_{i}=\left(y_{i-1}, y_{i}\right), l=1 \ldots n$ depend on the condition of a previous unit. In compliance with the method presented in [8], we denote a set of possible values of the condition vector of the $i$-th element by $Y_{i}, y_{i} \in Y_{i}$, the condition vector of the $i$-th subsystem composed of $i$ successively connected elements - by $y_{1 i}$, a set of possible values of the condition vector of the $i$-th subsystem:

$Y_{1 i}=\prod_{s=1}^{i} Y_{s}=\left\{y_{s} \in Y_{s}, s=\overline{1, i}\right\}, y_{1 i} \in Y_{1 i}$,

the vector of the process complex composed of $n$ successively connected elements:

$y_{1 n}=\prod_{i=1}^{n} Y_{i}=\left\{y_{i} \in Y_{i}, i=\overline{1, n}\right\}$,

a set of possible values of the condition vector of a process complex at a mining and concentration plant - by $Y_{1 n}, y_{1 n} \in Y_{1 n}$, the vector of parameters of the $i$-th element - by $K$, and a set of its values - by $K_{i}, K_{i} \in K_{i}$. It should be noted that in this case, $Y_{i}$ indicates technological constraints of a corresponding element of the technological complex.

where $\Theta$ is an operator of the grinding unit; $\left\{Q_{1}^{(\text {Slurry })}\right\},\left\{r_{1}[d], s_{1}[d]\right\}$ are vectors of output values; $\left\{Q_{0}^{(\text {Ore })}, Q_{0}^{(\text {Water })}\right\}$ is a vector of controlling actions; $\left\{r_{0}[d], s_{0}[d]\right\}$ is a vector of disturbance actions (the characteristic of the input flow of ore materials); $t$ is a time variable.

The separating unit (a spiral classifier, a deslimer, a hydrocyclone, a magnetic separator) as an operator assumes the following form:

$\left\{\begin{array}{l}\left\{Q_{2}^{(I)}, r_{2}^{(I)}[d], s_{2}^{(I)}[d]\right\}, \\ \left\{Q_{2}^{(I I)}, r_{2}^{(I I)}[d], s_{2}^{(I I)}[d]\right\}\end{array}\right\}=\Lambda_{2}\left(\begin{array}{l}\left\{Q_{1}^{(\text {Slurry })}\right\}, \\ \left\{r_{1}[d], s_{1}[d]\right\}, t\end{array}\right)$

where $\Lambda$ is an operator of the separating unit; $\left\{Q_{2}^{(I)}, r_{2}^{(I)}[d], s_{2}^{(I)}[d]\right\}$ are vectors of output values (discharge, middlings); $\left\{Q_{2}^{(I I)}, r_{2}^{(I I)}[d], s_{2}^{(I I)}[d]\right\}$ are vectors of output values (sands, tailings); $\left\{Q_{1}^{\text {(Slurry) }}\right\}$ are vectors of controlling actions; and $\left\{r_{1}[d], s_{1}[d]\right\}$ is a vector of disturbance actions (characteristic of the input flow of ore materials). 
The operator of the grinding unit is characterised by several inputs and outputs (MIMO).

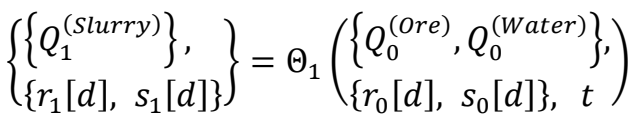

Absolutely analytical representation of the operator of the grinding unit $\Theta_{1}$ is impossible due to complexity of connections between output and input signals.

Among such signals in grinding, there are operator elements such as the following:

- redistribution (change of sizes) of particles in the output flow of ore materials:

$\left\{r_{1}[d]\right\}=\Theta_{1}^{r}\left(\left\{Q_{0}^{(\mathrm{P})}, Q_{0}^{(\mathrm{B})}\right\},\left\{r_{0}[d], s_{0}[d]\right\}, t\right)$

- redistribution (as a result of changed sizes) of Fe content in size classes of the output flow of ore materials:

$\left\{s_{1}[d]\right\}=\Theta_{1}^{r}\left(\left\{Q_{0}^{(\mathrm{P})}, Q_{0}^{(\mathrm{B})}\right\},\left\{r_{0}[d], s_{0}[d]\right\}, t\right)$

The operator of the separation unit in the same way as that of the grinding unit is characterised by multiple inputs multiple outputs (MIMO). At the same time, the separating unit has two output flows of ore materials; this doubling of the number of output values is comparable to the grinding unit.

$$
\left\{\begin{array}{l}
\left\{Q_{2}^{(I)}, r_{2}^{(I)}[d], s_{2}^{(I)}[d]\right\}, \\
\left\{Q_{2}^{(I I)}, r_{2}^{(I I)}[d], s_{2}^{(I I)}[d]\right\}
\end{array}\right\}=\Lambda_{2}\left(\begin{array}{l}
\left\{Q_{1}^{(\Pi)}\right\}, \\
\left\{r_{1}[d], s_{1}[d]\right\}, t
\end{array}\right)
$$

As in the case of designing a mathematical model of the grinding unit, absolutely analytical representation of the operator of the separating unit $\Lambda_{2}$ is impossible because of complex connections between output and input signals.

Among such signals in grinding, there are operator elements such as the following:

- redistribution (change of sizes) of particles in the output flow of ore materials:

$$
\begin{aligned}
& \left\{r_{2}^{(I)}[d]\right\}=\Lambda_{2}\left(\left\{Q_{1}^{(\Pi)}\right\},\left\{r_{1}[d], s_{1}[d]\right\}, t\right) ; \\
& \left\{r_{2}^{(I I)}[d]\right\}=\Lambda_{2}\left(\left\{Q_{1}^{(\Pi)}\right\},\left\{r_{1}[d], s_{1}[d]\right\}, t\right),
\end{aligned}
$$

- redistribution (as a result of changed sizes) of Fe content in size classes of the output flow of ore materials:

$$
\begin{aligned}
& \left\{s_{2}^{(I)}[d]\right\}=\Lambda_{2}\left(\left\{Q_{1}^{(\Pi)}\right\},\left\{r_{1}[d], s_{1}[d]\right\}, t\right) ; \\
& \left\{s_{2}^{(I I)}[d]\right\}=\Lambda_{2}\left(\left\{Q_{1}^{(\Pi)}\right\},\left\{r_{1}[d], s_{1}[d]\right\}, t\right),
\end{aligned}
$$

It should be noted that while using the material balance equation, one of the separating units can be calculated by values of another output. For example, the output parameter $\left\{r_{2}^{(I I)}[d]\right\}$ can be calculated by the known output parameter $\left\{r_{2}^{(I)}[d]\right\}$ and the input one $\left\{r_{1}[d]\right\}$.

Iron ore processing by process units (a cycle, a scheme) is characterised by a separation characteristic $\varepsilon(\xi)$ - a function of extracting elementary fractions depending on physical properties of particles $\xi$ of ore materials [32].

Dependency $\beta(\xi)$ of the useful component content on physical properties $\xi$ of particles is one of the basic characteristics of ore composition (32). Inside each fraction, separate particles can have different content of the component; a set $\bar{\beta}_{1}, \bar{\beta}_{2}, \ldots, \bar{\beta}_{n}$ and the function $\beta(\xi)$ provide average values of the content inside a fraction. It is worth noting that in separating ore particles by the property $\xi$, the value of the useful component content $\beta$ is secondary. Ore materials and concentration products are identified by the change of the physical property $\xi$ of particles in a certain range $\left[\xi_{\min }, \xi_{\max }\right]$ due to available mineral aggregates. The output of the $i$-th fraction $\left[\xi_{i}, \xi_{i+1}\right]$ is determined as a ratio of mass of its particles to total mass of particles of all fractions in a range of [ $\left.\xi_{\min }, \xi_{\max }\right]$ :

$\bar{\gamma}_{i}=\gamma\left(\xi_{i}\right) \Delta \xi_{i}=P_{i} / \sum_{i=1}^{n} P_{i}$

where $\gamma\left(\xi_{i}\right)$ is mass of the $i$-th fraction in the mixture, i.e. a discrete analogue of the differential function of distributing particles according to the physical property $\xi ; \Delta \xi_{i}$ is fraction size; $P_{i}$ is productivity by the $i$-th fraction.

Final fractions are extracted by separating the total range [ $\xi_{\min }$, $\left.\xi_{\max }\right]$ of the changes of the physical property $\xi$ of the particles' mixture by some number of final fractions $\Delta \xi_{1}, \Delta \xi_{2}, \ldots, \Delta \xi_{n}$ [32]. Extraction of the solid final fraction $\left[\xi_{i}, \xi_{i}+\Delta \xi_{i}\right]$ into concentrate results in equality to the ratio of productivity of the solid of the given fraction in the concentrate $P_{i \mathrm{~K}}$ and the input material $P_{i \mathrm{Bx}}$.

$\bar{\varepsilon}_{i \mathrm{~K}}=\frac{P_{i \mathrm{~K}}}{P_{i \mathrm{BX}}}=\frac{Q_{\mathrm{K}} \bar{\gamma}_{i \mathrm{~K}}}{Q_{\mathrm{Bx}} \bar{\gamma}_{i \mathrm{BX}}}=\frac{Q_{\mathrm{K}} \gamma_{i \mathrm{~K}}\left(\xi_{i}\right) \Delta \xi_{i}}{Q_{\mathrm{BX}} \gamma_{i \mathrm{Bx}}\left(\xi_{i}\right) \Delta \xi_{i}}$

where $Q_{\mathrm{K}}, Q_{\mathrm{BX}}$ are productivities of the solid in the concentrate and the input material, respectively, t/h; $\bar{\gamma}_{i \mathrm{~K}^{\mathrm{K}}} \bar{\gamma}_{i_{\mathrm{BX}}}$ is output of a fraction in the concentrate and the input material, respectively; $\gamma_{i \text { к }}(\xi), \gamma_{i_{\text {вх }}}(\xi)$ are distribution of the solid by fractions in the concentrate and the input material, respectively. Application of the given formula to each fraction enables a set of final extractions of fractions $\bar{\varepsilon}_{{ }_{\mathrm{K}}}, \bar{\varepsilon}_{2 \mathrm{~K}}, \ldots, \bar{\varepsilon}_{n \mathrm{~K}}$. After fulfilling the condition $\Delta \xi_{i} \rightarrow 0, n \rightarrow \infty$, the mentioned set is transformed into a continuous function - a separation characteristic [32]

$\varepsilon_{\mathrm{K}}(\xi)=\frac{Q_{\mathrm{K}} \gamma_{\mathrm{K}}(\xi) d \xi}{Q_{\mathrm{BX}} \gamma_{\mathrm{BX}}(\xi) d \xi}=\bar{\gamma}_{\mathrm{K}} \frac{\gamma_{\mathrm{K}}(\xi)}{\gamma_{\mathrm{BX}}(\xi)}$

where $\bar{\gamma}_{\mathrm{K}}=Q_{\mathrm{K}} / Q_{\mathrm{BX}}$ is the concentrate yield, unit fraction.

According to the method of experimentally determining the separation characteristic presented in [32], there is a need to measure productivity of the input material $Q_{\mathrm{BX}}$ and the concentrate $Q_{\mathrm{K}}$. Next, fraction analysis of samples of the input material and the concentrate should be performed to define distribution functions $\gamma_{\mathrm{BX}}(\xi), \gamma_{\mathrm{K}}(\xi)$, followed by calculations using Eq. (18).

The density of distributing mass of fractions by sieve composition is described by Weilbull distribution [30]

$r[d]=A a d^{a-1} e^{-A d^{a}}$

to which the equation of the distribution function $R[<d]=1-$ $e^{-A d^{a}}$ corresponds. The Rosin-Rammler equation of granulometric composition by the total residue on the sieve with the cell $d$ assumes the form of:

$R[>d]=e^{-A d^{a}}$

After changing the numerical value of the factor $a$, Eq. (20) enables describing a wide range of curves [30]. With $a>1$, the density curve reaches its maximum and then decreases asymptot- 
ically; with $a<1$ the curve looks like a hyperbole. The larger the indicator $A$, the more concave the curve of granulometric composition. With $a=1 \mathrm{Eq}$. (19) changes into the one-parameter law of exponential distribution.

Eq. (20) is linearised with double logarithmation -

$\ln (-\ln R[>d])=\ln A+a \ln d$

The size of the sieve cell $d_{\max }=D$, and the residue on which it equals $v$ (i.e. $v=0,05$ ), will correspond to the maximum statistic size of ore particles $d_{\max }[30]$

$R\left[>d_{\max }\right]=v=e^{-A d_{\max }^{a}}$

After substituting $A$ into Eq. (20), because of the maximum size of a particle, the expression assumes the form:

$R[>d]=e^{\ln v\left(d / d_{\max }\right)^{a}}$

There are some technological products (i.e. classifier sands) with no fine fractions; this fact does not allow application of Eq. (20) to the product like that. Correction for $d_{\text {min }}$ can be considered if we shift the coordinate origin by a value of $d_{\min }$ on the abscissa axis, i.e. transform the equation into the form suggested in [30]

$R[>d]=e^{-A\left(d-d_{\min }\right)^{a}}$

In this form, the equation satisfies any lower boundary value. The distribution density expressed by Eq. (24) is similar to Eq. (19):

$$
r\left[d_{i}\right]=A a\left(d_{i}-d_{\min }\right)^{a-1} e^{-A\left(d_{i}-d_{\min }\right)^{a}}
$$

The considered dependencies are also applied to the description of distributing the useful component mass (metal) of fractions [30].

$S[>d]=e^{-B\left(d_{i}-d_{\min }\right)^{b}}$

An equation similar to that of the distribution density presented in Eq. (25) assumes the following form:

$$
\begin{aligned}
& s[d]=B b\left(d-d_{\min }\right)^{b-1} e^{-B\left(d-d_{\min }\right)^{b}} \\
& S[>d]=\frac{e^{-B\left(d-d_{\min }\right)^{b}}-e^{-B\left(d_{\max }-d_{\min }\right)^{b}}}{1-e^{-B\left(d_{\max }-d_{\min }\right)^{b}}}
\end{aligned}
$$

Eqs (26) and (25) are linearised with double logarithmisation in the coordinate system $Y=\ln (-\ln S[>d])$ and $X=$ $\ln \left(d-d_{\text {min }}\right)$. The parameters of distributing the components, $\mathrm{B}$ and $b$, determine the character of the distribution curve of the granulometric composition and metal in the product.

Thus, the aggregate of both distributions enables full description of product composition in technological terms [30]. For example, based on distribution of mass of a product and that of metal in it, distribution of metal content by size fractions with $d_{\min }=0$ can be described in the following way:

$\alpha\left[d_{i}\right]=\frac{s\left[d_{i}\right]}{r\left[d_{i}\right]} \alpha_{0}=\frac{\alpha_{0} B b}{A a} d_{i}^{b-a} e^{A d_{i}^{a}-B_{i}^{b}}$
In a similar way, we write metal content in a fraction of larger (smaller) size by means of the ratios [30]

$\alpha[>d]=\frac{s[>d]}{R[>d]} \alpha_{0}=\frac{e^{-B d^{b}}}{e^{-A d^{a}}} \alpha_{0}$

$\alpha[<d]=\frac{s[<d]}{R[<d]} \alpha_{0}=\frac{1-e^{-B d^{b}}}{1-e^{-A d^{a}}} \alpha_{0}$

Thus, to form a mathematical model of iron ore processing in technological units, it is necessary to identify parameters of the dependencies presented above.

\section{RESEARCH RESULTS}

To calculate factors of the Rosin-Rammler equation based on experimental data gathered from the results of sieve analysis, the method suggested by L.P. Shupov [30] can be utilised. On the first stage, sieve analysis data determine total yield of fractions by the formulae: for the fraction $r\left[d_{1}\right]-R\left[>d_{1}\right]=r\left[d_{1}\right]$; for the fraction $r\left[d_{i}\right]-R\left[>d_{i}\right]=r\left[d_{1}\right]+r\left[d_{2}\right]+\cdots+r\left[d_{i}\right]$; for the fraction $r\left[d_{m}\right]-R\left[>d_{m}\right]=1$. While doing the research (Fig. 3), the authors consider the following size fractions of ore particles: $+3,-3+1,-1+0.5,-0.5+0.25,-0.25+0.125$, $-0.125+0.071,-0.071+0.056,-0.056+0.044,-0.044+0$. The testing results of the concentration line were obtained during the operations under the supervision of T.A. Oliinyk $[12,24]$.

To calculate factors of metal distribution $B$ and $b$ for each fraction (Fig. 4), metal content $\alpha\left[d_{i}\right]$ and metal share for this fraction are determined:

$s\left[d_{i}\right]=r\left[d_{i}\right] \alpha\left[d_{i}\right] / \alpha_{0}$

where $\alpha_{0}$ is total content of metal in the product. The metal share in the fraction is larger than $\mathrm{d}$ :

$S\left[>d_{i}\right]=s\left[d_{1}\right]+s\left[d_{2}\right]+\cdots+s\left[d_{i-1}\right]+s\left[d_{i}\right]$

To determine the factors of the Rosin-Rammler equation in (30), the least square method is used. After linearising the expression in Eq. (20) by double logarithmation, we obtain:

$\ln (-\ln R[>d])=\ln A+a \ln d$

we denote

$Y_{i}^{(R)}=\ln \left(-\ln R\left[>d_{i}\right]\right) ; Z_{i}^{(R)}=\ln d_{i}$,

and for the useful component content

$\ln (-\ln S[>d])=\ln B+b \ln d$;

$Y_{i}^{(S)}=\ln \left(-\ln S\left[>d_{i}\right]\right) ; Z_{i}^{(S)}=\ln d_{i}$,

Parameters of the Rosin-Rammler equation for different points of the technological line are presented in Tab. 1.

Parameters of the Rosin-Rammler equation for mathematical modelling of Fe content distribution by size classes of ore particles along the concentration line for different process line points are presented in Tab. 2. 


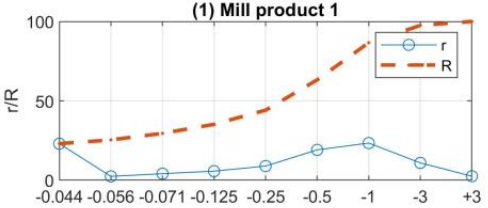

(4) Separator prod. 1(2)

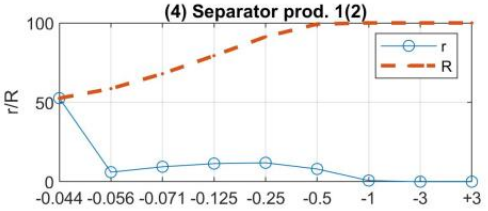

(7) Separator prod. 2

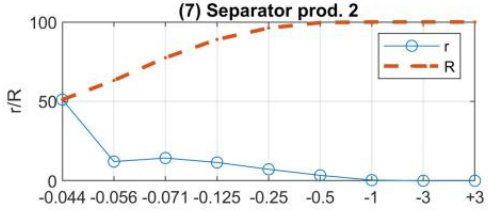

(10) Separat. prod. 3

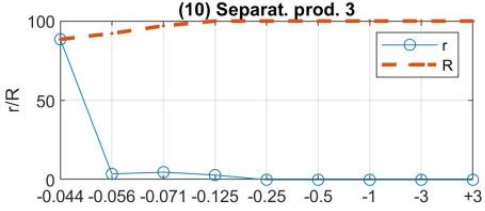

(13) H-cyclone overflow 3

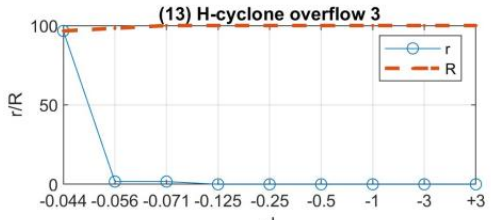

(2) Classif. prod. 1

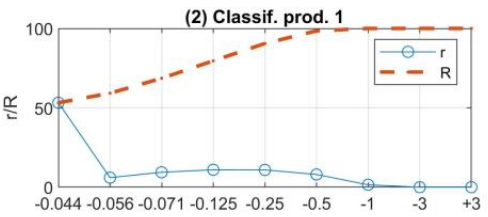

(5) H-cyclone underflow 2

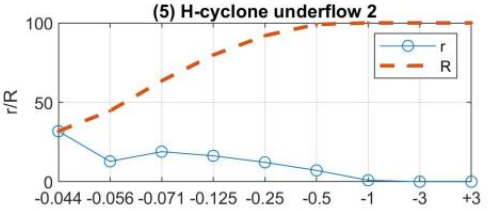

(8) H-cyclone overflow 2

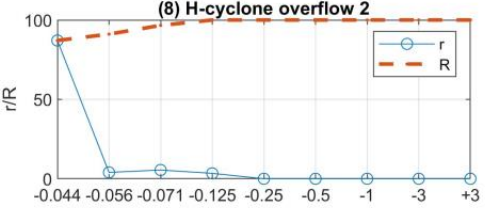

(11) H-cyclone underflow 3

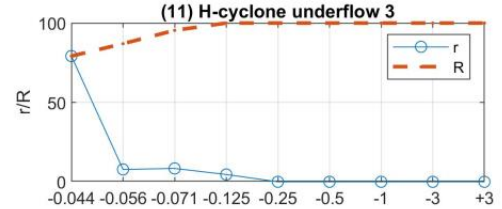

(14) Deslimer underflow 2

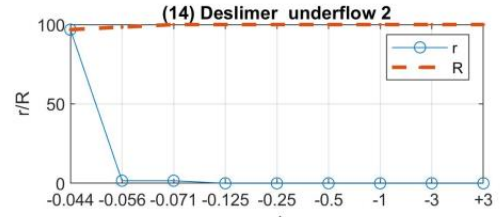

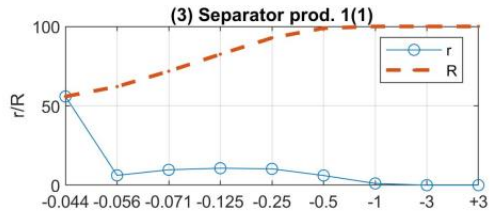

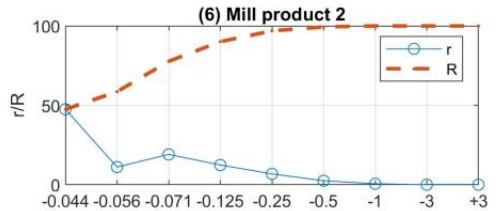

(9) Deslimer underflow 1

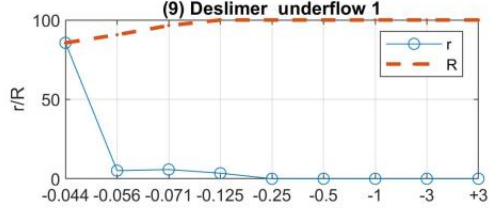

(12) Mill product 3

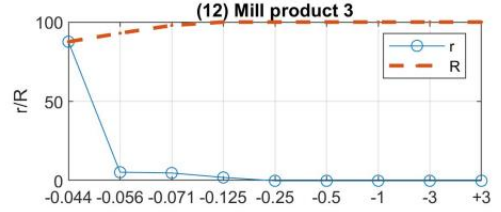

(15) Separator prod. 3

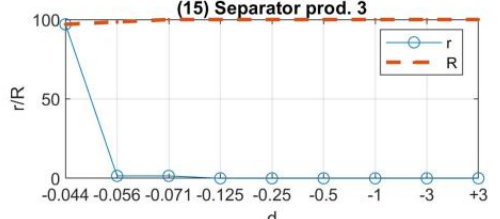

Fig. 3. Total yield of fractions in control points along the concentration line

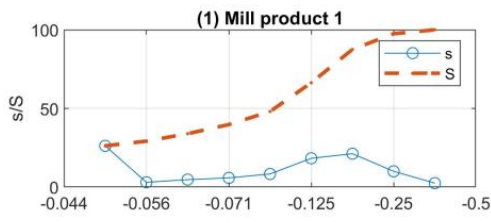

(4) Separator prod. 1(2)

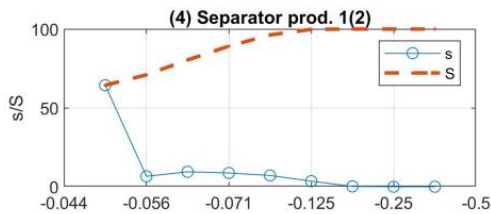

(7) Separator prod. 2

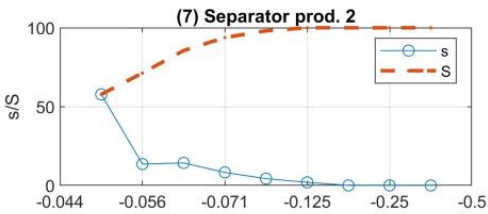

(10) Separat. prod. 3

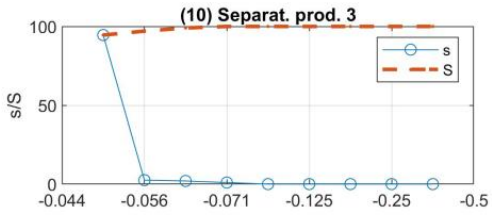

(13) H-cyclone overflow 3

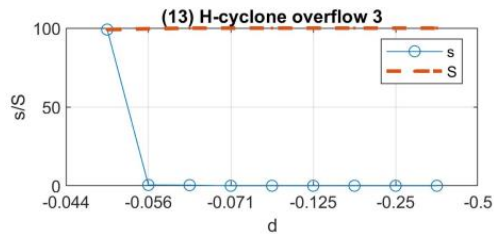

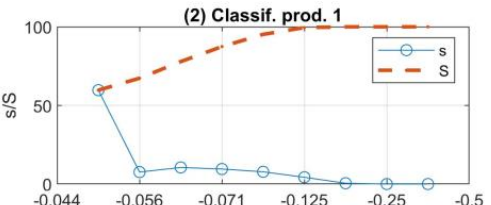

(5) H-cyclone underflow 2

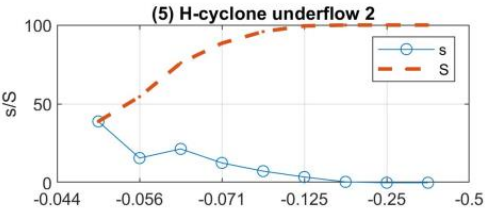

(8) H-cyclone overflow 2

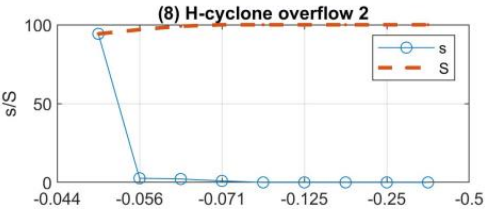

(11) H-cyclone underflow 3
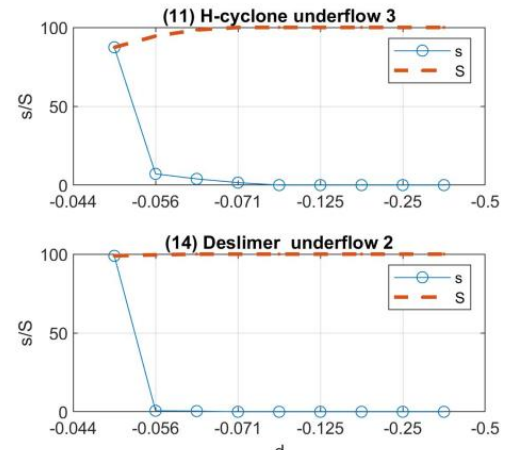
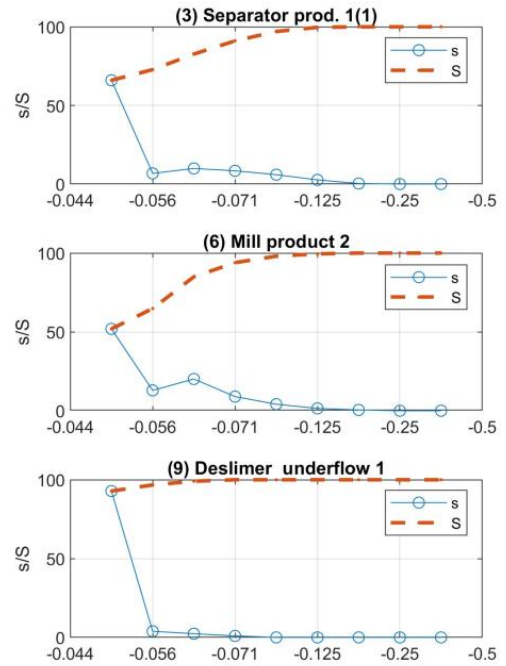

(12) Mill product 3
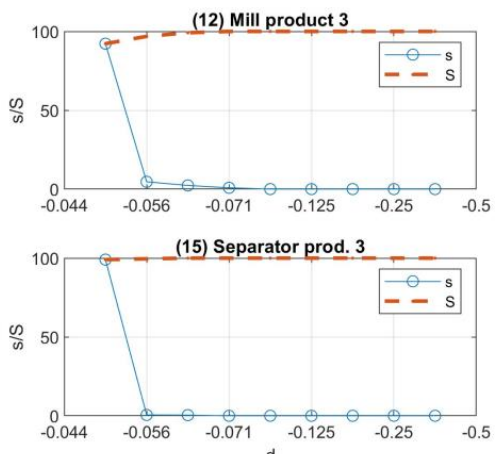

Fig. 4. Metal share in the fraction in control points along the concentration line 
Tab. 1. Rosin-Rammler equation factors for distributing ore particles by size classes $(R)$

\begin{tabular}{|l|c|c|c|c|}
\hline \multicolumn{1}{|c|}{ Unit } & Factor A & Factor a & Determination factor & Mean square error \\
\hline (1) Mill discharge 1st stage \#1 & 0.0368 & 1.9400 & 0.8775 & 11.7944 \\
\hline (2) Classifier discharge \#1 & 0.5924 & 0.8162 & 0.9004 & 6.3519 \\
\hline (3) Mag. separation 1st feed, 1st stage \#1/\#2 & 0.6612 & 0.7841 & 0.9054 & 5.7896 \\
\hline (4) Mag. separation 2nd feed, 1st stage \#1/\#2 & 0.5767 & 0.8354 & 0.8972 & 6.5903 \\
\hline (5) Hydrocyclone sands 2nd stage & 0.2716 & 1.3088 & 0.9726 & 4.6582 \\
\hline (6) Mill discharge 2nd stage & 0.5365 & 1.0084 & 0.9597 & 4.2967 \\
\hline (7) Mag. separation 2nd stage & 0.6173 & 0.9121 & 0.9609 & 3.8813 \\
\hline (8) Hydrocyclone discharge 2nd stage & 1.9728 & 0.5106 & 0.9201 & 1.4593 \\
\hline (9) Deslimer sands 1st stage. & 1.8733 & 0.5436 & 0.9363 & 1.4275 \\
\hline (10) Mag. product 3rd stage & 2.0908 & 0.4914 & 0.9224 & 1.2758 \\
\hline (11) Hydrocyclone sands 3rd stage & 1.5101 & 0.6462 & 0.9484 & 1.8387 \\
\hline (12) Mill discharge 3rd stage & 2.0425 & 0.5471 & 0.9573 & 0.9749 \\
\hline (13) Hydrocyclone discharge 3rd stage & 3.3499 & 0.4278 & 0.9423 & 0.3087 \\
\hline (14) Deslimer sands 2nd stage & 3.4106 & 0.4216 & 0.9420 & 0.2912 \\
\hline (15) Mag. product 4th stage & 3.4752 & 0.4152 & 0.9418 & 0.2736 \\
\hline
\end{tabular}

Tab. 2. Factors of Rosin-Rammler equation for distributing Fe content by size classes (S)

\begin{tabular}{|l|c|c|c|c|}
\hline \multicolumn{1}{|c|}{ Unit } & Factor B & Factor b & Determination factor & Mean square error \\
\hline (1) Mill discharge 1st stage \#1 & 0.0728 & 1.5968 & 0.9418 & 0.2736 \\
\hline (2) Classifier discharge \#1 & 0.7806 & 0.7478 & 0.9418 & 0.2736 \\
\hline (3) Mag. separation 1st feed, 1st stage \#1/\#2 & 0.9579 & 0.6790 & 0.9418 & 0.2736 \\
\hline (4) Mag. separation 2nd feed, 1st stage \#1/\#2 & 0.9015 & 0.6884 & 0.9418 & 0.2736 \\
\hline (5) Hydrocyclone sands 2nd stage & 0.4103 & 1.1733 & 0.9418 & 0.2736 \\
\hline (6) Mill discharge 2nd stage & 0.6482 & 0.9729 & 0.9418 & 0.2736 \\
\hline (7) Mag. separation 2nd stage & 0.7910 & 0.8580 & 0.9418 & 0.2736 \\
\hline (8) Hydrocyclone discharge 2nd stage & 2.8185 & 0.4344 & 0.9418 & 0.2736 \\
\hline (9) Deslimer sands 1st stage. & 2.6107 & 0.4935 & 0.9418 & 0.2736 \\
\hline (10) Mag.product 3rd stage & 2.8679 & 0.4243 & 0.9418 & 0.2736 \\
\hline (11) Hydrocyclone sands 3rd stage & 2.0485 & 0.6049 & 0.9418 & 0.2736 \\
\hline (12) Mill discharge 3rd stage & 2.5394 & 0.5340 & 0.9418 & 0.2736 \\
\hline (13) Hydrocyclone discharge 3rd stage & 4.6735 & 0.3412 & 0.9418 & 0.2736 \\
\hline (14) Deslimer sands 2nd stage & 4.5014 & 0.3614 & 0.9418 & 0.2736 \\
\hline (15) Mag. product 4th stage & 4.6428 & 0.3421 & 0.9418 & 0.2736 \\
\hline
\end{tabular}

Abonyi et al. [1] considers identification of fuzzy models with the structure suggested in [31]. This fuzzy model is composed of a set of rules in the following form:

$$
\begin{gathered}
R_{i_{1}, \ldots, i_{n}}: \text { if } z_{1} \text { is } A_{1, i_{1}} \text { and } \ldots \text { and } z_{n} \text { is } A_{n, i_{n}} \\
\text { then } y=f_{i_{1}, \ldots, i_{n}}\left(z_{1}, \ldots, z_{n}\right)
\end{gathered}
$$

where $\mathrm{n}$ is the number of inputs, $\bar{z}=\left[z_{1}, \ldots, z_{n}\right]$ is the vector containing all the inputs of the fuzzy model and $A_{j, i_{j}}\left(z_{j}\right)$ is the $i_{j}$ th fuzzy set of preconditions for the j-th input. The same symbol is applied to the fuzzy set and its membership function. $M_{j}$ is the number of fuzzy sets in the j-th input domain. $f_{i_{1}, \ldots, i_{n}}(\bar{z})$ is a (crisp) output function. For the given input vector $\bar{z}$ the output of the fuzzy model $y$ is calculated as weighted:

$y=$

$\sum_{i_{1}=1}^{M_{1}} \ldots \sum_{i_{n}=1}^{M_{n}} \beta_{i_{1}, \ldots, i_{n}} f_{i_{1}, \ldots, i_{n}}\left(z_{1}, \ldots, z_{n}\right) / \sum_{i_{1}=1}^{M_{1}} \ldots \sum_{i_{n}=1}^{M_{n}} \beta_{i_{1}, \ldots, i_{n}}$

where the weight $\beta_{i_{1}, \ldots, i_{n}}>0$ is the overall truth value of the $i_{1} \ldots i_{n}$-th rule calculated by the formula:

$\beta_{i_{1}, \ldots, i_{n}}=\prod_{j=1}^{n} A_{j, i_{j}}\left(z_{j}\right)$ 
To determine fuzzy sets in rule preconditions in Abonyi et al. [1], a triangular membership function is used:

$a_{j, i_{j}}=\operatorname{core}\left(A_{j, i_{j}}\left(z_{j}\right)\right)=\left\{z_{j} \mid A_{j, i_{j}}\left(z_{j}\right)=1\right\}$

where $a_{j, i_{j}}$ are kernels of fuzzy sets.

The set carrier is determined by kernels of adjacent fuzzy sets:

$A_{j, i_{j}}\left(z_{j}\right)=\frac{z_{j}-a_{j, i_{j}-1}}{a_{j, i_{j}}-a_{j, i_{j}-1}}, a_{j, i_{j}-1} \leq z_{j} \leq a_{j, i_{j}} ;$

$A_{j, i_{j}}\left(z_{j}\right)=\frac{a_{j, i_{j}+1}-z_{j}}{a_{j, i_{j}+1}-a_{j, i_{j}}}, a_{j, i_{j}} \leq z_{j} \leq a_{j, i_{j}+1}$.

The above-mentioned method of determination guarantees that the total of membership functions is equal to one. These constraints enable obtainment of interpreted bases of rules. The output evaluation method presented in (1) can be applied without being bound to certain membership functions. As the product operator in Eq. (39) is applied to the connector 'AND', total values of truth satisfy the conditions:

$\sum_{i_{1}=1}^{M_{1}} \ldots \sum_{i_{n}=1}^{M_{n}} \beta_{i_{1}, \ldots, i_{n}}=1$

Thus, Eq. (2) can be simplified in the following way (1):

$y=\sum_{i_{1}=1}^{M_{1}} \ldots \sum_{i_{n}=1}^{M_{n}}\left[\left(\prod_{j=1}^{n} A_{j, i_{j}}\left(z_{j}\right)\right) f_{i_{1}, \ldots, i_{n}}\left(z_{1}, \ldots, z_{n}\right)\right]$

In many fuzzy identification methods, a nonlinear autoregressive exogenous model (NARX), of both neural-network and fuzzy types, is used. This model determines nonlinear dependency between previous inputs-outputs and a forecast output (1):

$y(k+1)=F\left(\begin{array}{l}y(k), \ldots, y\left(k-n_{y}+1\right), u\left(k-n_{d}\right), \ldots \\ \ldots, u\left(k-n_{u}-n_{d}+1\right)\end{array}\right)$

where $n_{y}, n_{u}$ are maximum lags of input and output signals, respectively, $n_{d}$ is discrete delay time and $\mathrm{F}$ is reflection of the fuzzy model.

Tagaki-Sugeno fuzzy NARX-like model interpolates between local linear invariant (LTI) ARX models in this way (1):

$$
\begin{aligned}
R_{i_{1}, \ldots, i_{n}}: \text { if } z_{1}(k) & \text { is } A_{1, i_{1}} \text { and } \ldots \text { and } z_{n}(k) \text { is } A_{n, i_{n}} \text { then } \\
y^{i_{1} \ldots, i_{n}}(k+1) & =\sum_{i=1}^{n_{y}} a_{i}^{i_{1} \ldots, i_{n}} y(k-i+1)+ \\
& +\sum_{i=1}^{n_{u}} b_{i}^{i_{1}, \ldots, i_{n}} u\left(k-i-n_{d}+1\right)+c^{i_{1}, \ldots, i_{n}}
\end{aligned}
$$

where $\bar{z}(k)$ is usually a subset $\left\{y(k), \ldots, y\left(k-n_{y}+1\right)\right.$, $\left.u\left(k-n_{d}\right), \ldots, u\left(k-n_{u}-n_{d}+1\right)\right\}$. This fuzzy model can be considered as linear parameter-varying (LPV):

$\sum_{i=1}^{n_{y}} a_{i} y(k-i+1)=\sum_{i=1}^{n_{u}} b_{i} u\left(k-i-n_{d}+1\right)+c$

where

$$
\begin{aligned}
& a_{0}=1 ; \\
& a_{i}=-\sum_{i_{1}=1}^{M_{1}} \ldots \sum_{i_{n}=1}^{M_{n}}\left(\prod_{j=1}^{n} A_{j, i_{j}}\left(z_{j}\right)\right) a_{i}^{i_{1}, \ldots, i_{n}}, \quad i=1, \ldots, n_{y} ; \\
& b_{i}=\sum_{i_{1}=1}^{M_{1}} \ldots \sum_{i_{n}=1}^{M_{n}}\left(\prod_{j=1}^{n} A_{j, i_{j}}\left(z_{j}\right)\right) b_{i}^{i_{1}, \ldots, i_{n}}, \quad i=1, \ldots, n_{u} ; \\
& c=\sum_{i_{1}=1}^{M_{1}} \ldots \sum_{i_{n}=1}^{M_{n}}\left(\prod_{j=1}^{n} A_{j, i_{j}}\left(z_{j}\right)\right) c^{i_{1}, \ldots, i_{n}} \quad i=1, \ldots, n_{y},
\end{aligned}
$$

Parameters $a_{i}, b_{i}, c$ are usually constrained in boundaries of convex sets (polytopes) separated by parameters of some rules. This results from Eq. (47) and the fact that degrees of membership total one, as is shown in Eq. (6). It is indicated that some types of a-priori knowledge about the LTI model can be expressed as linear constraints of inequality $[1,33]$ :

$\Lambda_{L T I} \theta_{L T I} \leq \omega_{L T I}$

where $\theta_{L T I}=\left[a_{1}, a_{2}, \ldots, a_{n_{y}}, b_{1}, \ldots, b_{n_{u}}, c\right]$ denotes parameters of the LTI model. These constraints of the LTI model parameters determine a set of convex parameters $\Omega$ :

$\Omega=\left\{\theta_{L T I} \mid \Lambda_{L T I} \theta_{L T I} \leq \omega_{L T I}\right\}$

Abonyi et al. (1) suggests the method of introducing a-priori data into fuzzy model. The set of parameters $\theta_{L T I}$ of the LTI model can be a subset $\Omega$. Through the convexity $\Omega$ and the convexity of the applied method of fuzzy outputs, it is sufficient to check constraints for the rule outputs. This means that constraints can be adjusted to Takegi-Sugeno fuzzy model:

$\Lambda^{*} \theta_{i_{1}, \ldots, i_{n}} \leq \omega^{*}$

where

$\theta_{i_{1}, \ldots, i_{n}}=$

$\left[a_{1}^{i_{1}, \ldots, i_{n}}, a_{2}^{i_{1}, \ldots, i_{n}}, \ldots, a_{n_{y}}^{i_{1}, \ldots, i_{n}}, b_{1}^{i_{1}, \ldots, i_{n}}, \ldots, b_{n_{u}}^{i_{1}, \ldots, i_{n}}, c^{i_{1}, \ldots, i_{n}}\right] \quad$ denotes parameters of the $i_{1}, \ldots, i_{n}$-th local model, $\Lambda^{*}, \omega^{*}$ are global constraints of the fuzzy model.

\section{CONCLUSIONS}

Technological concentration units as controlled objects are operators that transform vectors of input variables into those of output variables. Correspondingly, the process line of concentrating iron ore materials is considered as a sequence of connected concentration units, some of which partially return ore materials to the previous unit. The output product of the final concentration unit in the process line is the end product of the whole line. Characteristics of ore such as distribution of ore particles by size and distribution of Fetot and $\mathrm{Fe}_{\mathrm{mag}}$ content by size classes are considered.

The operator of the separating unit, similar to that of the grinding one, is characterised by several inputs and outputs (MIMO). At the same time, the separating unit has two output flows of ore materials, thus doubling the number of output values in relation to the grinding unit.

As in the case of designing a mathematical model of the grinding unit, absolutely analytical representation of the operator of the separating unit is impossible due to complexity of connections between output and input signals. Among such signals in grinding, one should distinguish between operator elements such as redistribution (change of size) of particles in input flows of ore materials and redistribution of $\mathrm{Fe}$ content in size classes of output flows of ore materials.

Processing of iron ore materials by process units (a cycle, a scheme) is characterised by a separation characteristic - namely the function of extracting elementary fractions depending on physical properties of ore particles.

The results of fraction analysis of ore samples in different points of the process line provide experimental definition of the separation characteristics and numerical values of the Rosin- 
Rammler equation factors.

To identify dependencies that cannot be analytically described, the hybrid approach, accompanied by the TakagiSugeno fuzzy models and triangular membership functions determining fuzzy sets in preconditions, is used. To identify fuzzy sets in rule preconditions, triangular membership functions are used.

Introduction of a-priori data on iron ore concentration as constraints for model parameters is a promising trend of further research, since it enables increased accuracy of identification with limited availability of experimental data.

\section{REFERENCES}

1. Abonyi J, Babuska JR, Verbruggen HB, Szeifert F. Incorporating prior knowledge in fuzzy model identification. International Journal of Systems Science. 2000; 31:657-667. doi.org/10.1080/002077200290966.

2. Bilenko LF. Zakonomernosti izmelcheniya $v$ barabannyih melnitsah [Regularities of grinding in drum mills]. Moscow: Nedra [in Russian]; 1984.

3. Bogatikov VN, Kulakov AG. Ispolzovanie gibridnoy neyronnoy seti v raskryitii neopredelennosti funktsii razrusheniya materia-la pri izmelchenii [Application of the hybrid neural network in disclosing ambiguity of the material destruction function in grinding]. Vestnik Kostromskogo gosudarstvennogo universiteta - Bulletin of Kostroma State University. 2006; 11:29-31 [in Russian].

4. Bogatikov VN, Kulakov AG, Reev SN. Imitatsionnoe modelirovanie tehnologicheskogo protsessa sokrascheniya krupnosti materiala pri izmelchenii $v$ agregate nepreryivnogo deystviya s zamknutyim tsiklom. Informatsionnyie tehnologii v regionalnom razvitii [Simulations of size reduction processes in grinding in the closed-loop continuous unit. Information technologies in regional development]. Apatityi [in Russian]. 2006.

5. Bublikov A, Tkachov V. Automation of the control process of the mining machines based on fuzzy logic. Naukovyi Visnyk Natsionalnoho Hirnychoho Universytetu. 2019; 3:112-118.

6. Golik V, Komashchenko V, Morkun V, Burdzieva O. Metal deposits combined development experience. Metallurgical and Mining Industry. 2015; 7(6):591-594.

7. Golik VI, Razorenov YI, Efremenkov AB. Recycling of metal ore mill tailings. Applied Mechanics and Materials. 2014; 682:363-368.

8. Grechnikov AF, Grishanov DG, Pavlov OV, Pushkov AN. Soglasovannoe upravlenie tehnologicheskim kompleksom s posledova-telno soedinennyimi elementami [Cohesive control over a technological comples with sequentially connected elements]. Vestnik Samarskogo gosudarstvennogo aerokosmicheskogo universiteta - Bulletin of Samara State Aerospace University. 2003; 2:29-33 [in Russian].

9. Gurevich LS. Modelirovanie strukturyi potokov v barabannoy melnitse [Modelling of flow structures in drum mills]. Obogaschenie rud - Ore Concentration. 1989; 2:34-37 [in Russian].

10. Kafarov VV, Verdiyan MA. Matematicheskie modeli strukturyi potoka materiala $v$ melnitsah [Mathematical models of the structure of material flows in mills]. Moscow: Tsement; 1977. [in Russian].

11. Kafarov VV, Glebov MB. Matematicheskoe modelirovanie osnovnyih protsessov himicheskih proizvodstv: Uchebnoe posobie dlya vuzov [Mathematical modelling of basic processes of chemical enterprises: Teaching manual for universities]. Moscow: Vysshaya shkola; 1991 [in Russian].
12. Khmil IV. Osoblivostl tehnologlyi podrlbnennya magnetitovih kvartsitlv v umovah ob'Emnogo nerlvnomlrno-komponentnogo stisnennya. Dis. kandidata tehn. nauk: 05.15.08 [Peculiarities of grinding technology of magnetite quartzite under volumetric irregular-component compression: Candidate's thesis (Engineering) 05.15.08]; 2016. [in Ukrainian].

13. Kramer YB. O kinetike nepreryivnogo izmelcheniya [On kinetics of continuous grinding]. Fiziko-mehanicheskie problemyi razrabotki poleznyih iskopaemyih - Physical and mechanical problems of mineral mining. 1986; 130-131 [in Russian].

14. Kruglov VV. Iskusstvennyie neyronnyie seti. Teoriya i praktika [Artificial neural networks. Theory and practice]. Moscow: Goryachaya liniya-Telekom; 2001 [in Russian].

15. Linch AD. Tsiklyi drobleniya i izmelcheniya [Cycles of crushing and grinding]. Moscow: Nedra; 1981 [in Russian].

16. Maryuta AN, Kachan YG, Bunko VA. Avtomaticheskoe upravlenie tehnologicheskimi protsessami obogatitelnyih fabrik [Automated control over technological processes at cancentrating plants]. Moscow: Nedra; 1981 [in Russian].

17. Morkun V, Morkun N, Tron V, Hryshchenko S. Synthesis of robust controllers of technological units control systems of ore-dressing factory. Eastern-European Journal of Enterprise Technologies. 2018; 1-2(91):37-47.

18. Morkun V, Morkun N, Pikilnyak A. The adaptive control for intensity of ultrasonic influence on iron ore pulp, Metallurgical and Mining Industry. 2014; 6:8-11.

19. Morkun V, Morkun N, Tron V. Distributed closed-loop control formation for technological line of iron ore raw materials beneficiation. Metallurgical and Mining Industry. 2015; 7:16-19.

20. Morkun V, Morkun N, Tron V. Distributed control of ore beneficiation interrelated processes under parametric uncertainty, Metallurgical and Mining Industry. 2015; 8:18-21.

21. Morkun V, Morkun N, Tron V. Identification of control systems for ore-processing industry aggregates based on nonparametric kernel estimators, Metallurgical and Mining Industry. 2015; 1:14-17.

22. Morkun V, Morkun N, Tron V. Model synthesis of nonlinear nonstationary dynamical systems in concentrating production using Volterra kernel transformation, Metallurgical and Mining Industry. 2015; 10:6-9.

23. Morkun V, Tron V. Automation of iron ore raw materials beneficiation with the operational recognition of its varieties in process streams, Metallurgical and Mining Industry. 2014; 6: 4-7.

24. Oliinyk TA. Doslidzhennia vplivu dinamlchnih efektlv visokoenergetichnogo ultrazvuku na gazovi bulbashky u pulpl dlya upravllnnya parametrami yiyi gazovoi fazy u protsesi flotatsii: zvlt pro NDR [Investigation into dynamic effects of high-energy ultrasound on gas bubbles in slurry to control parameters of its gas phase in floatation: research report]. DVNZ «Krivorlzkiy natslonalniy unlversitet». Kryvyi Rih; 2016 [in Ukrainian].

25. Pevzner LD, Kostikov VG, Lettiev OA, Kostikov RV. Razrabotka i issledovanie matematicheskoy modeli protsessa rudoizmelche-niya [Development of and investigation into the mathematical model of ore grinding]. Gornyiy informatsionno-analiticheskiy byulleten (nauchnotehnicheskiy zhurnal) - Mining information-analytical bulluten (scientific and technical journal). 2012; 11:312-320 [in Russian].

26. Porkuian O, Morkun V, Morkun N, Serdyuk O. Predictive control of the iron ore beneficiation process based on the Hammerstein hybrid model, Acta Mechanica et Automatica. 2019; 13(4):262-270. 
27. Porkuian O, Morkun V, Morkun N. Measurement of the ferromagnetic component content in the ore suspension solid phase, Ultrasonics. 2020; $105: 106103$.

28. Stupnik N, Kalinichenko V, Pismennij S, Kalinichenko E. Features of underlying levels opening at «ArcelorMittal Krivyi Rih» underground mine. In: New Developments in Mining Engineering 2015: Theoretical and Practical Solutions of Mineral Resources Mining. 2015; 39-44.

29. Stupnik M, Kolosov V, Pysmennyi S, Kovbyk K. Selective mining of complex stuctured ore deposits by open stope systems. E3S Web of Conferences. 2019; 123:01007.

30. Shupov LP. Modelirovanie i raschet na EVM shem obogascheniya [Simulation and computer calculation of concentration schemes]. Moscow: Nedra; 1980 [in Russian].

31. Takagi T, Sugeno M. Fuzzy identification of systems and its application to modeling and control. IEEE Trans. Systems, Man and Cybernetics. 1985; 15(1):116-132.

32. Tihonov ON. Zakonomernosti effektivnogo razdeleniya mineralov $v$ protsessah obogascheniya poleznyih iskopaemyih [Regularities of effective separation of minerals in concentration processes]. Moscow: Nedra; 1984 [in Russian].

33. Tulleken HJAF. Gray-box modelling and identification using pysical knowledge and Bayesian techniques. Automatica. 1993; 29:285-308.

34. Tuz AA, Sanaeva GN, Prorokov AE, Bogatikov VN. Nechiotkologicheskiy podhod $k$ modelirovaniyu protsessa izmelcheniya $v$ agregate nepreryivnogo deystviya s zamknutyim tsiklom Aktsionernogo Obschestva «Kovdorskiy gorno-obogatitelnyiy kombinat» [Fuzzylogic approach to modelling grinding in the closed-loop continuous unit of the JSC „Kovdor Mining Concentrating Works"]. Internetzhurnal "NAUKOVEDENIYE" - Internet-journal "SCIENCE STUDIES". 2016; 8(1). https://cyberleninka.ru/article/n/nechyotko-logicheskiy-podhod-kmodelirovaniyu-protsessa-izmelcheniya-v-agregate-nepreryvnogodeystviya-s-zamknutym-tsiklom [in Russian].
35. Tuz AA, Sanayeva GN, Prorokov AY, Bogatikov VN. Upravlenie tehnologicheskimi protsessami izmelcheniya i osnovnyie napravleniya ih avtomatizatsii [Control over grinding processes and basic trends of their automation]. Vestnik evraziyskoy nauki - Bulletin of Eurasian Science. 2016; 8(2):130-131 [in Russian].

36. Zlatorunskaya GE. Otsenka izmelchaemosti droblenoy rudyi po ee granulometricheskoy harakteristike [Assessment of ground ore by its granulometric characteristic]. Obogaschenie rud - Ore Concentration. 1985; 2 [in Russian].

37. Zolotkov NF, Dyomin VT, Kontsevoy AV, Smirnov SV. Modernizatsiya i razvitie sistem avtomatizirovannogo kontrolya i upravleniya [Updating and development of automated control systems]. Gornyi zhurnal - Mining Journal. 2012; 10:91-96 [in Russian].

Vladimir Morkun: (D) https://orcid.org/0000-0003-1506-9759

Vitalii Tron: (D) https://orcid.org/0000-0002-6149-5794

Vadym Zymohliad: (D) https://orcid.org/0000-0002-6822-6140 